\title{
Mental Health Issues during COVID-19 Pandem- ic: Directions for Future Research
}

\author{
Anirotul Qoriah ${ }^{1}$, Aftina Nurul Husna ${ }^{2}$ \\ \{anirotulqoriah@mail.unnes.ac.id ${ }^{1}$, anhusna@ummgl.ac.id ${ }^{2}$ \} \\ Universitas Negeri Semarang, Semarang Indonesia ${ }^{1}$, Universitas Muhammadiyah Magelang, \\ Magelang, Indonesia ${ }^{2}$
}

\begin{abstract}
Prolonged stress due to fear and uncertainty about Covid-19 pandemic situation might hamper people's ability to recover and live a new normal. However, public mental health during Covid-19 pandemic is relatively neglected topic in coronavirus-related study in Indonesia. Lacking of theoretical explanation regarding the nature of this issue, this article aims to explore conceptual progress documented in internationally published articles and to identify emerging topics on mental health issue and Covid-19 pandemic. We systematically reviewed 52 scientific articles consisting of original research, observation, literature review, letters to editor, and commentaries and concluded seven main themes: background and research methods, psychological responses, compromised quality of life, the vulnerable groups, well-being promotion efforts, potential of telemental health, and factors influencing wellbeing. Despite of limitations due to the method used, the findings may inform researchers and practitioners who concern in this issue to do similar investigation in Indonesia.
\end{abstract}

Keywords: mental health issues, Covid-19 pandemic, systematic literature review

\section{Introduction}

Covid-19 pandemic becomes a formidable non-natural disaster with seemingly no end in the near future. Covid-19 is an infectious disease caused by severe acute respiratory syndrome coronavirus 2 (SARS-CoV-2). It firstly emerged from Wuhan, China, in late December 2019 and now the outbreak has affected almost all countries around the world. World Health Organization (WHO) declared it a Global Public Health Emergency since January 30, and a Global Pandemic on March, 11. In only a half year, per June 2020, there are more than 450.000 fatalities with more than five millions confirmed cases from 216 countries [1].

In Indonesia, as Covid-19 begins to spread extensively in several provinces, on April 13 2020, Presidential Decree Number 12/ 2020 on Stipulation of Non-Natural Disasters of the Spread of COVID-19 as a National Disaster was signed by President 
Joko Widodo [2]. To prevent Covid-19 patients overwhelming medical facilities, some local governments implement Pembatasan Sosial Berskala Besar (PSBB)/ Large Scale Social Restriction to limit people mobility and suppress virus transmission. People are told to stay at home and do self-quarantine after travel. Covid-19 prevention campaigns are so massive in media telling people to frequently wash hands, to use facial mask, to keep physical distance in public places, to avoid physical contact, and so on. School and workplace are closed for months; students and workers do their routines from home.

Impact of Covid-19 pandemic is devastating either for the infected people nor the uninfected by the disease. Medical personels, doctors and nurses, in the frontline of war against the virus are constantly under the risk. They must follow strict health protocols to avoid getting infected themselves, meanwhile personal protective equipment (PPE) is in shortage. Some must watch death of patients who cannot survive and see the grief of families left behind. Society in general is also greatly impacted especially by restrictive policy to contain the spread of the virus. Cities are under lockdown. Public places such as schools, markets, offices, and houses of worship, are closed. Study and work must be done online from home, creating imbalance in family life. People in isolation hardly meet and interact one each other and thus, lose social support. Economic activities are halted, leading to increasing number of unemployment and poverty.

Initially the spread of Covid-19 is health-related issue, but since it also causes social and economic disturbances, public mental health becomes a major concern by WHO [3]. People's well-being are at stake, not only on those who are previously healthy, but also those who already have existing mental health conditions. In some places, stigmatisation of people with Covid-19 as well as xenophobic attitude toward certain ethnic/ religious groups perceived as the source of the disease are alarming indications of social unrest. Worsening condition inevitably drives people to experience considerable degree of negative feelings such as loneliness, despair, fear, and worry. Drastic changes in daily life urge people to get ready and adapt to a new normal, to live together cautiously with the virus.

As scientists are still racing against the time to create vaccine and find drugs to cure Covid-19, mental health issue is considerably a less prioritized research focus. However, for long-term importance, anticipation of the impacts of prolonged stress experienced by medical personel and general public would be a necessity to help people becoming more resilient. In developing countries with weak society safety net and underdeveloped health systems, strenghten people from the inside would be a transformative effort. It brings opportunity for people to recover and live a new normal.

In Indonesia, research on mental health during Covid-19 pandemic is relatively low and not studied systematically. Topics of research are dominated by high concerns on bio-chemical, medical and epidemiological aspects of the disease [4-7], impact, policy and regulation regarding Covid-19 in health, education, and economic sectors [8-15], and factors contributing in Covid-19 occurence and recovery, such as weather [16] and sunlight exposure [17]. Therefore, this article tries to address the mental health issue during Covid-19 pandemic by conducting a systematic literature review. It aims to explore the progress of research and thoughts in this area and to map out emerging themes. Hopefully it will bring insights and more comprehensive 
knowledge for future investigation which would be beneficial for the development of theories and practice in Covid-19 related problems.

\section{Methods}

\subsection{Literatures Searching and Selecting Procedures}

This qualitative study systematically reviews existing scientific on mental health issue during Covid-19 pandemic. A search was undertaken using search engine Google Scholar and keywords "mental health and Covid-19" and "Covid-19 in Indonesia". A total of 58 articles were retrieved which are all published in 2020 following the outbreak. The source of articles are ranging from journals in psychiatry, psychology, public health, medicine, clinical nursing, and forensic science. After thoroughly reviewing the contents, six articles were excluded because they are a brief case report in particular country. The rest 52 articles consist of original research, observational research, literature review, letters to editor, and editorials/ commentary related to mental health issues during Covid-19 pandemic.

\subsection{Methodology of Literature Analysis}

We conducted content analysis with procedures delineated as follow: 1) reading the articles carefully and taking some notes regarding important/ meaningful facts or ideas, 2) categorizing emerging themes and clustering them into fewer but broader main themes, 3) describing the main themes based on facts and ideas, and 4) summarizing the findings by presenting it using a table. Subsequently, we discuss the findings as conceptual framework for future research agenda.

\section{Results and discussion}

Table 1. Outline of Findings

\begin{tabular}{|c|c|c|}
\hline No. & Main Themes & Sub Themes \\
\hline 1. & $\begin{array}{l}\text { Background and } \\
\text { research methods } \\
\text { on Covid-19- } \\
\text { related mental } \\
\text { health issue }\end{array}$ & $\begin{array}{l}\text { (1) Investigation of the nature of mental health problems as } \\
\text { impacts of Covid-19 } \\
\text { (2) Proposed methods to study mental health during Covid-19 } \\
\text { pandemic } \\
\text { (3) Research questions regarding mental health and Covid-19 } \\
\text { pandemic }\end{array}$ \\
\hline 2. & $\begin{array}{l}\text { Psychological } \\
\text { responses } \\
\text { Covid-19 }\end{array}$ & $\begin{array}{l}\text { (1) Contextual factors behind psychosocial stress } \\
-\quad \text { Social restrictive policy (quarantine, social } \\
\\
\text { - } \text { distancing, self-isolation) } \\
\text { (2) } \text { Kindsuption in education, economic, and work life. } \\
-\quad \text { Emotional reactions } \\
-\quad \text { Unhealthy behavior } \\
-\quad \text { Non-compliance behavior }\end{array}$ \\
\hline 3. & $\begin{array}{l}\text { Compromised } \\
\text { quality of life as }\end{array}$ & $\begin{array}{l}\text { (1) Dysfunction in social life (stigmatization, xenophobia, } \\
\text { mass hysteria, \& panic buying) }\end{array}$ \\
\hline
\end{tabular}




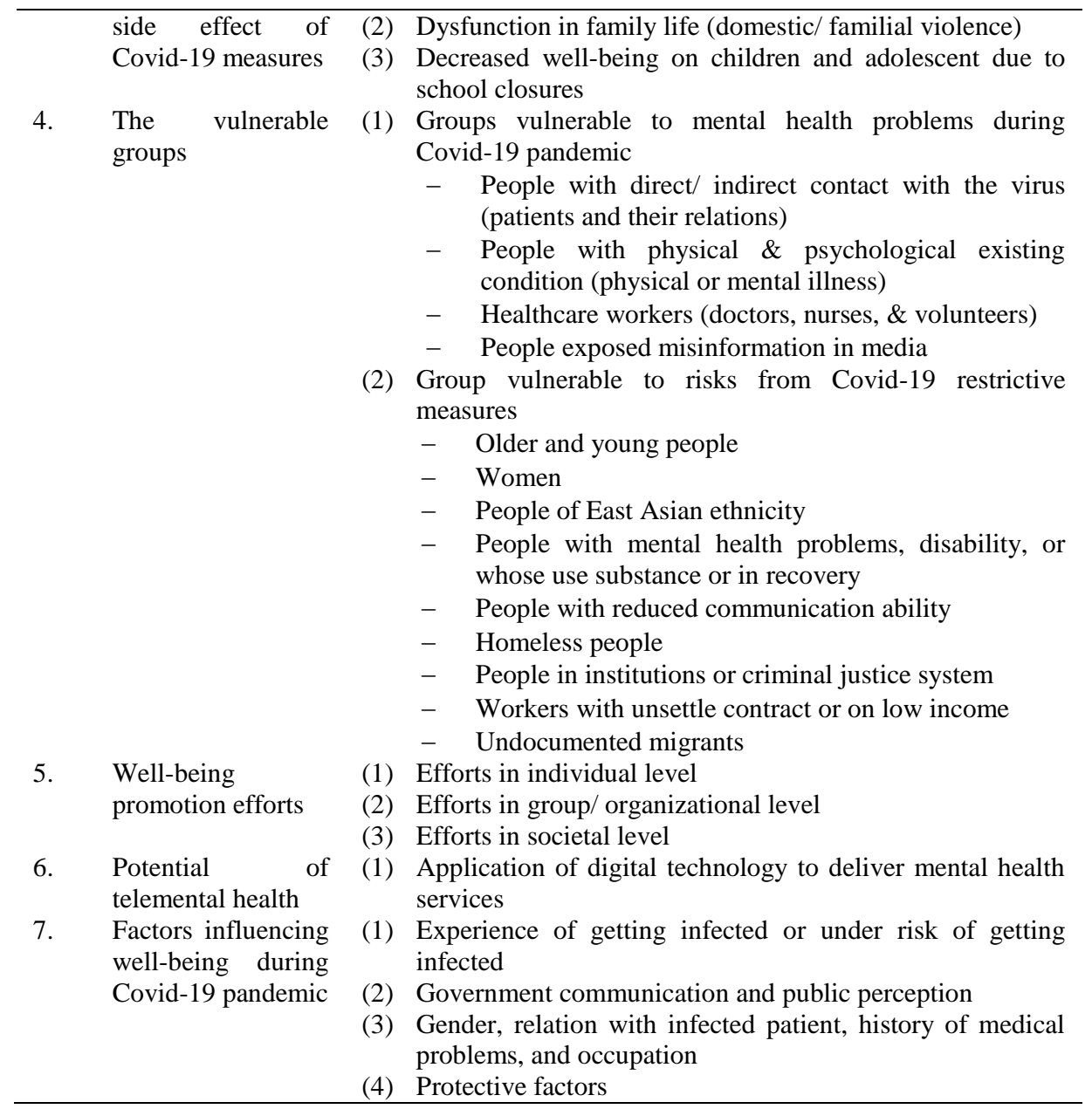

\subsection{Background and Research Methods on Covid-19-Related Mental Health Issues}

Concerns about mental health issues during Covid-19 arise from observation of people behaviors as response to the disease as a threat. In early weeks of pandemic, media reported several phenomena, such as mass panic buying and increasing xenophobia (accusation and assault) toward Chinese-looking people in several coutries. Public expressions characterized by anxiety and feeling unsafe are considered the early signs of mental health issue entailing Covid-19 outbreak. Negative societal behaviors are rooted in people's responses to fear and intolerance of uncertainty. Uncertainty alarms people to behave in extreme way in order to reduce feared uncontrollable situations. Also, when cause, progression, and outcome of the disease are not yet clear, misinformations are virally spread in social media and these lead people to posit close-minded attitute to deal with situation [18].

It takes some times for scientists starting to give more scrutiny on the nature of the problems as more incidents happened like suicide and self-harm $[19,20]$ and fami- 
ly violence $[21,22]$. Later survey research on population hardest hit by the outbreak at that time such as in China and Italy and on high risk groups such as healthcare workers, shows increasing cases of stress, anxiety, and depression [23,24]. Covid-19 precautionary measures such as self-isolation, quarantine, and social distancing/ restriction to general population cause environmental changes and subsequently, unintended psychological impacts $[25,26]$. The scale of the problem are so widespread and calling for action to set out long-term strategies.

Mental health research is very encourged to support the mitigation effort. Various attempts are conducted to describe, understand and predict the progress of the issues, even though still in fragmented way by researcher around the world. First, by doing extensive literature review to find insights from previous mental health studies related to outbreaks in the past (e.g SARS, and MERS). Second, using survey (nonexperimental quantitative study) to observe and monitor psychological needs and trend of mental health status of general population directly or indirectly affected by Covid-19. Surveys relied on self-report and may be conducted online utilizing surveillance application provided by government to be downloaded by citizens. Third, using qualitative approach to probe individuals' experience living under social restriction and having to cope with socioeconomic effects of the policies used to manage the pandemic. Qualitative research is also useful to understand causal mechanisms associated with poor mental health and identify souces of support available or protective factors [26]. Findings from multidisciplinary research would later be crucial information for intervention programs.

Several research quastions are proposed by Holmes [26]: 1) What is the effect of Covid-19 on risk of anxiety, depression, and other outcomes, such as self-harm and suicide? 2) What is the optimal structure for a mentally healthy life during the outbreak and the period of social restriction? 3) What are the mental health consequences of the Covid-19 lockdown and social isolation for vulnerable groups, and how can these be mitigated under pandemic conditions? 4) What is the effect of repeated media consumption about Covid -19 in traditional and social media on mental health, and how can well-being be promoted? 5) What are the best methods for promoting well-being and adherence to behavioural advice about Covid-19 while enabling mental wellbeing and minimising distress?

\subsection{Psychological Responses to Covid-19}

Covid-19 pandemic affects individuals and overall society through several mechanisms: economy effects, social distancing and isolation, family relationship, healthrelated behavios, disruption of social services, disrupted education and transportation, social disorder, and psychosocial effects [25,27]. Social restrictive policy (social distancing and isolation) drastically is altering what is familiar and complicating various aspects of daily life [25]. Social distancing may cause loss of income for many people in several ways. Some people may work at home, but some others lose their work completely. For those who work from home, school closures require them to provide childcare. This harshly affects family with low income and single parent. Low income increases psychosocial stress and those who are already poor will be worstly hit [27].

Social and economic changes due to public health emergency drive the psychosocial effects of Covid-19. These effects can range from emotional reactions (e.g. elevated stress, anxiety, and depression), unhealthy behaviors (e.g. substance use, 
violance, and panicking), and non-compliance to public health instructions (e.g. refuse to do self-isolation/ social restriction or to wear face mask) $[28,29]$.

Even though Covid-19 mortality rate is lower than other respiratory diseases such as SARS and MERS, the fear of getting affected are prevalent in the mind of millions people around the globe. The fear does not solely originate from the life threatening disease. Multidimensional impacts of the disease, such as huge economic losses, the burden of quarantine and self-isolation, travel restriction, and strict monitoring and screening also play roles in shaping people's mind during pandemic. In addition, wide spread misinformation and misinfodemics in social media stir people to feel anxious [30]. Due to long-term destabilized mental health, increasing level of loneliness, depression, harmful alcohol and drug use, self-harm, suicidal behavior are expected to occur and anticipated [31]. Extreme fear and uncertainty, lowere perceived health, negative societal behavior, health risk behavior, and mental disorder are other psychosocial effects of Covid-19 that should be examined attentively [31,32].

Psychological responses to the impacts of Covid-19 has a unique role in shaping attitude and behavior. People's psychological reactions toward Covid-19 pandemic play critical role in adherence to public health measures and ability to cope with the threat of infection. Inadaptive psychological reactions to pandemic may lead to maladaptive behaviors, emotional distress and defensive responses such as rejecting vaccination. Without proper psychological intervention in community, this would lead to increased risk of infection [33]. Among adaptive psychological reactions is functional fear of Covid-19 (fears about contracting the virus, feeling personally at risk of infection) which significantly predict risk-mitigating behaviors [34].

\subsection{Compromised Quality of Life as Side Effect of Covid-19 Measures}

Strict measures taken by authority to control pandemic might reduce the spread of Covid-19, but at the expense of people's quality of life. The Covid-19 pandemic is getting beyond a just medical phenomena; it disrupts normality and causes social dysfunction. It is indicated by the presence of stigma, xenophobia, mass hysteria, and panic behavior. In the early days of pandemic, people are reported panicly buying medical and daily stuffs causing shortage of supplies in markets [30].

Problem related to family dysfunction arises in the form of increasing domestic/ familial violence during quarantine period. This problem is paradoxical to government effort keeping society safe from Covid-19 outside but unintendedly confining children, women, and elderly in a dangerous situation with the abuser inside the house $[22,35]$. For people living with abusive relationships, staying at home is not safe at all and going outside provides relief and opportunity to look for help. Restrictive measure of pandemic indirectly causes unemployment, reduced income, limited resources, and limited social support. Those problems are likely combined in the household and subsequently become risk factors for family violence $[21,22,36]$.

For children, decreased quality of life may link to the closures of school and campus. For children and adolescents with mental health needs like depression and autism, school closure means a lack of access to the resources they usually have through school such as peer-support group, psychological services, and school routines. For college and university students, souces of stress are related to dormitory evacuation and cancellation of anticipated important events such as final exam and 
graduation ceremonies. After graduation, they are anxious about job market they are prepared for [37].

\subsection{The Vulnerable Groups}

The pandemic of Covid-19 affects everyone, but the impact on some groups or communities may be greater. Vulnerable groups are those who suffer direct impact of Covid-19 or indirectly affected by Covid-19 via responses to Covid-19 precautionary and mitigating measures. It is important to continue giving support to these groups who may experience mental health and psychosocial effects of Covid-19 pandemic: 1) those who have been directly/ indirectly in contact with the virus, 2) those who are already vulnerable to biological or psychosocial stressors, 3) health professional because of higher level of exposure, and 4) people who are following bad news in media [38].

In general population, there are 13 groups of people at particular risk from responses to Covid-19: 1) older people (at highest risk of severe Covid-19, especially those who live alone and not adept to use online communication), 2) young people (affected by societal disruptions in education or work sectors, most at risk of poor employment in longer term), 3) women (especially those who play role in childcare during school closure and potential to be victims of family violence), 4) people of East Asian ethnicity (due to xenophobia and social stigma as the pandemic is associated with China), 5) people with mental health problems (at risk of social isolation), 6) people who use substance or in recovery (at risk of relapse or withdrawal), 7) people with disability (affected by disrupted social services), 8) people with reduced communication ability (including those who have learning disability and limited literacy hampering ability to receive information and messages in media), 9) homeless people (may be unable to self-isolate and affected by disrupted social services), 10) people in criminal justice system (may be unable to self-isolate in prison setting or contact family), 11) undocumented migrants (may have no access or be reluctant to get to health services), 12) workers with unsettle contract or self-employment (at highest risk of losing work and have no income), 14) people on low income (already have poor health and insecure work), and 14) people in institutions (who live together in care homes or special need facilities) [27].

Unquestionably, health-care workers in hospitals or clinics, volunteers, and social service personnel are vulnerable to experience psychological break down while fulfilling their duties. Healthcare workers especially are reported experiencing insomnia, burnout, depressive symptoms, and post-traumatic stress disorder [30,39-42]. Compared to non-clinical staff in hospital, front line medical staff with close contact with infected patients were 1.4 times more likely to feel fear, twice more likely to suffer anxiety and depression [43]. Working under extreme pressures and shortage of personal protective equipment/ PPE, doctors may be unable to balance their own physical and mental health care and with those of patients due to duty [24,44]. Doctors are likely to experience moral injury, a psychological distress that results from actions which violate moral or ethical code. Unattended moral injury may lead to PTSD or depression, while providing support before, during, and after the incident may help them to gain psychological growth [44]. 
Eight sources of anxiety on healthcare professionals are identified as follow: 1) access to appropriate personal protective equipment/ PPE, 2) being exposed to Covid19 at work and bringing the infection home, 3) not having rapid access to testing if they develop Covid-19 symptoms and concomitant fear of propagating infection at work, 4) uncertainty that their organization will support/take care of their personal and family needs if theydevelop infection, 5) access to childcare during increased work hours and school closures, 6) support for other personal and family needs as work hours and demands increase (food, hydration, lodging, transportation), 7) being able to provide competent medical care if deployed to a new area (eg, non-ICU nurses having to function as ICU nurses), and 8) lack of access to up-to-date information and communication [45].

The vulnerable groups are including those who endure quarantine for prolonged duration and with mental illness too [30,46,47]. Covid-19 pandemic measures such as area lockdown and personal hygiene instructions are likely to increase new onset Illness Anxiety Disorder in general population. On Obsessive Compulsive Disorder patients, especially those who have washing compulsion, their existing condition are likely getting worse. Disrupted daily routine and social rhythm increase stress level and may exacerbate people with depressive symptoms and chronic insomnia. [46]. Other vulnerable group are people with certain physical conditions such as Parkinson's Disease [48] and pregnancy [49]. Women in second and third trimester of pregnancy who have no worry about their health before pandemic are reported experiencing heightened health anxiety regarding their older relatives, their other children, their unborn baby, and their own health [49].

Lastly, patients and family members of infected patients are vulnerable too. Their experience are lacking exploration in previous literatures and their stories are less exposed in media too due to tendency to view mourning as a privat matter. Grief is a normal mourning that occur when death is expected. Grief is the most prevalent emotional response experienced by families left behind as common reactions after a loss. Grief is often accompanied with anxiety and depression or guilt and self-blame, and these contribute negatively to the quality of dying experience. Dynamic of grief on family members is related to social distancing/ isolation and inability to give proper funeral and burial for deceased patients [50].

\subsection{Well-Being Promotion Efforts}

Human-being has capacity to resilience so that most of affected people do not succumb to psychopathology during Covid-19 pandemic. People may find new strenght and experience personal growth as a result of adversity [29]. Normalization can be promoted through several ways: First, in individual level by 1) educating public about common stress responses like insomnia, panic attacks, health-related anxiety, fear of illness, increasing use of substance, irritability, isolation, and aggresion and 2) encouraging health-promoting behaviors and stress coping/ self-care methods such as sleep hygiene, activity scheduling, exercising, social connections, avoiding social media, and relaxation techniques [30].

Second, in group/ organizational level by 1) empowering family with knowledge about how to support and take care of its members, to facilitate social connection with significant others in isolation and loneliness [30], 2) integrating psychological intervention into health-care systems and communitity, and 3) providing psychological 
guidance in work place especially hospital to attend emotional well-being of healthcare workers $[40,51]$ as well as daily basic needs such as food, drink, rest facilities, and adequate PPE [42].

Third, in societal level by putting focus on people's mental health by infusing optimism and hope in mass communication practice [30,33,39]. Public health messages are suggested to focus on duties and responsibilities toward family, friends and fellow citizens with concern to the greater good [47].

\subsection{Potential of Telemental Health}

Digital technology begin to be applied in the effort of mitigating mental health issues during Covid-19 pandemic. Telemental health is the use of information and communication technology to provide mental health care remotely through for example video conferencing. Telemental health, tele-psychology, tele-psychiatry, or ehealth are new field of collaborative research between psychologists/ psychiatrists, digital technology experts, and computer scientists [32,52].

Telemental health technology can bridge the gap in practices of psychology and psychiatry which now are discouraged to be carried out face-to-face [32]. When people have to minimize unurgent trip to hospital, the use of technology for communication is increasing. Psychological service goes online is becoming alternative trend, for example in a successful case of treating children and adolescents with eating disorders during Covid-19 pandemic in Singapore [53]. To ensure continuity of mental health service and care, video conferencing psychotherapy and internet interventions are among alternative solutions, despite of their weaknesses due to the nature of computer-mediated communication. Previously, online therapy is doubted and never fully integrated into normal part of routine care practice. Covid-19 pandemic thus becomes catalyst for wider acceptance and adoption of online approach by mental health professionals [54].

\subsection{Factors Influencing Well-Being during Covid-19 Pandemic}

Well-being during Covid-19 pandemic is measured through whether mental health problems such as stress, anxiety, and depression are present on individuals, and how it affects their functioning in daily life/ quality of life. Poor well-being is indicated by the increase of mental/ psychological distress. We found several factors affecting people's of well-being:

a Experience of getting infected or under risk of getting infected. A study in China found that prevalence of depression is increasing in patients of Covid-19. However, both patients suffering Covid-19 and public in general together showing higher prevalence of depression comorbid with anxiety than individuals under quarantine. Depressed mood, somatic symptom, and anxious behavior indicated by becoming easily annoyed are reported in both groups too [55]. People under quarantine seemingly feel saver. Other than depression and anxiety, some people are reported to feel helpless, horrified, and apprehensive as well as increased stress from work [56].

b Government communication and public perception. Public perception of an insufficient government response in handling the pandemic is associated with lower mental well-being. People who perceive their government are in control as showed in capability to put strong actions (for example, announcing a 
nationwide lockdown) are more satisfied and thus have better mental well-being [57]. In other research in China, there is no immediate negative psychological effect of quarantine or no quarantine. Negative psychological consequences tend to raise from dissatisfaction with control measures implemented by the government. Poor communication causes failure ensuring the public that the quarantine or social restriction is acceptable and tolerable experience [58].

c Gender, relation with the infected patient, history of medical problems, and occupation. From a study conducted in Italy, being female was associated with higher levels of depression, anxiety, and stress. Having acquaintances infected was associated with increased levels of both depression and stress. History of stressful situations and medical problems was associated with higher levels of depression and anxiety. Having a family member infected and young person who had to work outside their domicile were associated with higher levels of anxiety and stress. [59].

d Protective factors. During Covid-19 pandemic, uncertainty and unpredictability in situation cause negative psychological impacts. However, some protective factors are found playing big role in moderating its severity and alleviating negativity: High confidence in medical personnel, perceived survivability, perceived low risk of infection, stisfaction with health information, and capability to implement personal precautionary measures [23].

\subsection{Discussion}

This literature study tries to fill the theoretical gap regarding Covid-19-related mental health issue. Through rigorous reading on international scientific literature, the thematic findings may inform researchers and mental health practitioners who concern with the issue specifically in Indonesia about how far the scientific endeavor has been going. We found seven main themes in literatures: background and research methods, psychological responses, compromised quality of life, the vulnerable groups, well-being promotion efforts, potential of telemental health, and factors influencing well-being. One of the themes, psychological responses to Covid-19, is expected and might seem familiar to those dwelling with mental health issue during a period of disaster in general. However, many emerging themes are novel to the recent Covid-19 outbreak.

Experiencing emotional distress such as fear, enxiety, and depression is a normal response people might show during disaster period and as the time goes, they would bounch back, adapt themselves, and continue living. It is mentioned that most people will not succumb into psychopathology after disaster [29]. However, in the context of Covid-19 pandemic, some factors should be taken into consideration because it is not like any other disaster in scale, duration, and severity in society. Natural and manmade disasters in general usually happen in only certain locality and with clear time of ending. Higher level of severity are experienced mostly by people directly impacted by the disaster. It gives chance for other unaffected community to give supports for the affected, so that general society may recover and turn to normal again. In comparison, Covid-19 pandemic is so widespred and left only few countries unaffected. The end of the pandemic is uncertain due to the absense of vaccine and countries are still struggling to contain its spread. In term of severity, millions people are directly affected as positive patients, while millions other are affected by its socially restrictive 
mitigation measures. Covid-19 pandemic thus is no longer health phenomena since it causes huge social and economic disturbances.

This nature of Covid-19 pandemic explains why there are many vulnerable groups whose well-being must be supported by mental health system. Those groups are classified into two main groups: group of people who experience psychosocial effect of Covid-19 pandemic and those who are at high risk from precautionary measures to Covid-19. The second group experinces compromised well-being both in societal and familial level. It would be necessary to conduct follow up studies to explore and identify psychological needs of each groups and to give psychological interventions as support for their recovery. This applied approach is still lacking original research. Several articles discussed well-being promotional efforts as commentary and suggestion for stakeholders. As Covid-19 pandemic happened in digital era, there is a growing interest to develop telemental health or the use of digital information and communication technology to deliver mental healthcare services such as psychotherapu and counselling. This alternative is promising as Covid-19 pandemic becomes the unexpected catalisator. Development of telemental health would be the next research interest in mental health science.

Reflecting on this progress, many studies can be done in Indonesia. In comparison to the other worst hit countries by coronavirus such as China, Iran, India, Italy, or United States of America, Indonesia has unique cultural situation in the region of South East Asia. Like other countries, Indonesia also experiences economic downturn due to the pandemic. However, its society presumably shows more resilience and embraces the new normal quite easily. From observation of Indonesian social life, people are rushed to come back to their previous routine after Large Scale Social Restriction is relaxed in some locals with exception in only few sectors such as education. Hyphothesized, religious beliefs may play big role in shaping Indonesians' mind so that they cannot be fearful or depressed any longer. Religious beliefs eases their emotional distress even though from scientific standpoint, it is discouraged because it may reduces alertness.

This literature study gives many insight for directions of future research especially in Indonesia. Using literature study, researcher may be able to find temporary answer based on available evidence before focusing it to a research question [60]. However, the results are challenged by several limitation especially in recent literature study. First, this study might not cover all available sources because researchers do not have access to any research database. The articles are searched using general search engine Google Scholar. Some articles were declined due to purchasing requierment. Second, the quality of findings is limited due to the quality of the sources which are dominated by commentary and observation articles. Despite of valuable informations found, they are lacking empirical evidence. Third, the findings are not free of subjectivity in the content screening process. The articles were retrieved from a vast array of scientific journal, from medicine to forensic science which are beyond both researchers's field of study (respectively, management and psychology). It is highly probable that some important facts are missed out. 


\section{Conclusion}

Covid-19 pandemic has attracted attention of many health professionals, psychologists, and psychatrists who concern with the mental status of effected populations around the world. Mental health issues are stem from inadaptive psychosocial response, especially those are are classified into vulnerable groups, ranging from emotional reactions, unhealthy behaviors, and non-complience to public health instructions. Efforts to promote well-being are suggested to be implemented in individual, group/ organizational, and societal level, which some begin to utilize digital technology. There is a need for more investigation in Indonesian context, either in form of prelimineary or follow-up study about: the effect of Covid-19 on heightened risk of psychological problems, the consequences of restrictive measures for vulnerable groups, the effect of media exposure, the structure and dynamic of mentally healthy individuals, the intervention to promote well-being, or the role of culture and religion in the response of Covid-19. The findings would be beneficial to help mitigating the consequence of pandemic and to support Indonesia society to enter the new normal in adaptive way.

\section{References}

[1] Novel coronavirus (COVID-19), https://www.who.int/bulletin/online_first/COVID19/en/, last accessed 21 June 2020.

[2] Gov't Declares COVID-19 Pandemic as National Disaster. https://setkab.go.id/en/govtdeclares-covid-19-pandemic-as-national-disaster/, last accessed 21 June 2020.

[3] Mental health and psychological resilience during the COVID-19 pandemic, https://www.euro.who.int/en/health-topics/health-emergencies/coronavirus-covid19/news/news/2020/3/mental-health-and-psychological-resilience-during-the-covid-19pandemic, last accessed 22 June 2020.

[4] Harapan H, Itoh N, Yufika A, Winardi W, Keam S, Te H. Coronavirus disease 2019 (COVID-19): A literature review. J Infect Public Health.2020;13:667-73.

[5] Khaerunnisa S, Kurniawan H, Awaluddin R, Suhartati S. Potential Inhibitor of COVID-19 Main Protease ( M pro ) from Several Medicinal Plant Compounds by Molecular Docking Study. Preprints. 2020;1-14.

[6] Setiati S, Azwar MK. COVID-19 and Indonesia. Acta Med Indones. 2020;52:84-9.

[7] Nuraini N, Khairudin K, Apri M. Modeling Simulation of COVID-19 in Indonesia based on Early Endemic Data. Commun Biomath Sci. 2020;3:1-8.

[8] Yunus NR, Rezki A. Kebijakan Pemberlakuan Lock Down Sebagai Antisipasi Penyebaran Corona Virus Covid-19. SALAM J Sos dan Budaya Syar-i. 2020;7:227-37.

[9] Telaumbanua D. Urgensi Pembentukan Aturan Terkait Pencegahan Covid-19 di Indonesia. QALAMUNA J Pendidikan, Sos dan Agama. 2020;12:59-70.

[10] Abidah A, Hidaayatullaah HN, Simamora RM, Fehabutar D, Mutakinati L. The Impact of Covid-19 to Indonesian Education and Its Relation to the Philosophy of "Merdeka Belajar." Stud Philos Sci Educ. 2020;1:38-49.

[11] Khasanah DRAU, Pramudibyanto H, Widuroyekti B. Pendidikan Dalam Masa Pandemi Covid-19. J Sinestesia. 2020;10:41-8.

[12] Pujilestari Y. Dampak Positif Pembelajaran Online Dalam Sistem Pendidikan Indonesia Pasca Pandemi Covid-19. 'Adalah Bul Huk Keadilan. 2020;4:49-56.

[13] Firman F, Rahayu S. Pembelajaran Online di Tengah Pandemi Covid-19. Indones J Educ Sci. 2020;2:81-9. 
[14] Muzakki F. The Global Political Economy Impact of Covid-19 and The Implication to Indonesia. Joutnal Soc Polit Sci. 2020;1:76-93.

[15] Suryahadi A, Al Izzati R, Suryadarma D. The Impact of COVID-19 Outbreak on Poverty: An Estimation for Indonesia (Draft). SMERU Work. Pap. Jakarta; 2020.

[16] Tosepu R, Gunawan J, Savitri D, Ode L, Imran A, Lestari H. Correlation between weather and Covid-19 pandemic in Jakarta, Indonesia. Sci Total Environ. 2020;725.

[17] Asyary A, Veruswati M. Sunlight exposure increased Covid-19 recovery rates: A study in the central pandemic area of Indonesia. Sci Total Environ. 2020;729.

[18] Usher K, Durkin J, Bhullar N. The COVID-19 pandemic and mental health impacts. Int J Ment Health Nurs. 2020;29:315-8.

[19] Mamun MA, Griffiths MD. First COVID-19 suicide case in Bangladesh due to fear of COVID-19 and xenophobia: Possible suicide prevention strategies. Asian J Psychiatr. 2020;51:102073.

[20] Sahoo S, Rani S, Parveen S, Singh AP, Mehra A, Chakrabarti S, et al. Self-harm and COVID-19 Pandemic: An emerging concern - A report of 2 cases from India. Asian J Psychiatr. 2020;51:102104.

[21] Humphreys KL, Myint MT, Zeanah CH. Increased Risk for Family Violence During the COVID-19 Pandemic. Pediatrics. 2020; 20200982.

[22] Campbell AM. An increasing risk of family violence during the Covid-19 pandemic: Strengthening community collaborations to save lives. Forensic Sci Int Reports. Elsevier B.V.; 2020;2:100089.

[23] Wang C, Pan R, Wan X, Tan Y, Xu L, Mcintyre RS, et al. A longitudinal study on the mental health of general population during the COVID-19 epidemic in China. Brain, Behav Immun J. 2020;87:40-8.

[24] Wong AH, Pacella-LaBarbara ML, Ray JM, Ranney ML, Chang BP. Healing the Healer: Protecting Emergency Healthcare Workers' Mental Health During COVID-19. Ann Emerg Med. American College of Emergency Physicians; 2020;1-6.

[25] Usher K, Bhullar N, Jackson D. Life in the pandemic: Social isolation and mental health. J Clin Nurs. 2020;1-2.

[26] Holmes EA, O'Connor RC, Perry VH, Tracey I, Wessely S, Arseneault L, et al. Multidisciplinary research priorities for the COVID-19 pandemic: a call for action for mental health science. The Lancet Psychiatry. 2020;547-60.

[27] Douglas M, Katikireddi SV, Taulbut M, McKee M, McCartney G. Mitigating the wider health effects of covid-19 pandemic response. BMJ. 2020;369:1-6.

[28] Rajkumar RP. COVID-19 and mental health: A review of the existing literature. Asian J Psychiatr. 2020;52:102066.

[29] Pfefferbaum B, North CS. Mental Health and the Covid-19 Pandemic. N Engl J Med. $2020 ; 1-3$.

[30] Banerjee D. The COVID-19 outbreak: Crucial role the psychiatrists can play. Asian J Psychiatr. 2020;50.

[31] Thakur V, Jain A. COVID 2019-suicides: A global psychological pandemic. Brain Behav Immun. 2020;

[32] Ćosić K, Popović S, Šarlija M, Kesedžić I. Impact of human disasters and Covid-19 pandemic on mental health: Potential of digital psychiatry. Psychiatr Danub. 2020;32:2531.

[33] Cullen W, Gulati G, Kelly BD. Mental health in the COVID-19 pandemic. QJM An Int J Med. 2020;1-2.

[34] Harper CA, Satchell LP, Fido D, Latzman RD. Functional Fear Predicts Public Health Compliance in the COVID-19 Pandemic. Int J Ment Health Addict. 2020;

[35] Bradbury-Jones C, Isham L. The pandemic paradox: The consequences of COVID-19 on domestic violence. J Clin Nurs. 2020;19:2047-9. 
[36] Usher K, Bhullar N, Durkin J, Gyamfi N, Jackson D. Family violence and COVID-19: Increased vulnerability and reduced options for support. Int J Ment Health Nurs. 2020;

[37] Lee J. Mental health effects of school closures during COVID-19. Lancet Child Adolesc Heal. Elsevier Ltd; 2020;4:421.

[38] Fiorillo A, Gorwood P. The consequences of the COVID-19 pandemic on mental health and implications for clinical practice. Eur Psychiatry. 2020;63:e32, 1-2.

[39] Burdorf A, Porru F, Rugulies R. The COVID-19 (Coronavirus) pandemic: Consequences for occupational health. Scand J Work Environ Heal. 2020;46:229-30.

[40] Galbraith N, Boyda D, McFeeters D, Hassan T. The mental health of doctors during the Covid-19 pandemic. BJPsych Bull. 2020;1-7.

[41] Pappa S, Ntella V, Giannakas T, Giannakoulis VG, Papoutsi E, Katsaounou P. Prevalence of depression, anxiety, and insomnia among healthcare workers during the COVID-19 pandemic: A systematic review and meta-analysis. Brain Behav Immun.; 2020;1-7.

[42] Walton M, Murray E, Christian MD. Mental health care for medical staff and affiliated healthcare workers during the COVID-19 pandemic. Eur Hear J Acute Cardiovasc Care. 2020;9:241-7.

[43] Lu W, Wang H, Lin Y, Li L. Psychological status of medical workforce during the COVID-19 pandemic: A cross-sectional study. Psychiatry Res. 2020;288.

[44] Greenberg N, Docherty M, Gnanapragasam S, Wessely S. Managing mental health challenges faced by healthcare workers during covid-19 pandemic. BMJ. 2020;368:10-2.

[45] Shanafelt T, Ripp J, Trockel M. Understanding and Addressing Sources of Anxiety among Health Care Professionals during the COVID-19 Pandemic. JAMA - J Am Med Assoc. 2020;323:2133-4.

[46] Chatterjee SS, Malathesh BC, Mukherjee A. Impact of COVID-19 pandemic on preexisting mental health problems. Asian J Psychiatr. 2020;51.

[47] Druss BG. Addressing the COVID-19 Pandemic in Populations With SeriousMental Illness. JAMA - J Am Med Assoc. 2020;E1-2.

[48] Helmich RC, Bloem BR. The Impact of the COVID-19 Pandemic on Parkinson's Disease: Hidden Sorrows and Emerging Opportunities. J Parkinsons Dis. 2020;10:351-4.

[49] Corbett GA, Milne SJ, Hehir MP, Lindow SW, O'connell MP. Health Anxiety and Behavioural Changes of Pregnant Women Durıng the Covid-19 Pandemic. Eur J Obstet Gynecol Reprod Biol. 2020;249:96-7.

[50] Wallace CL, Wladkowski SP, Gibson A, White P. Grief During the COVID-19 Pandemic: Considerations for Palliative Care Providers. J Pain Symptom Manage. Elsevier Inc; 2020;60:e70-6.

[51] Ripp J, Peccoralo L, Charney D. Attending to the Emotional Well-Being of the Health Care Workforce in a New York City Health System During the COVID-19 Pandemic. Acad Med. 2020;1-4.

[52] Whaibeh E, Mahmoud H, Naal H. Telemental Health in the Context of a Pandemic: the COVID-19 Experience. Curr Treat Options Psychiatry. Current Treatment Options in Psychiatry; 2020;

[53] Davis C, Ng KC, Oh JY, Baeg A, Rajasegaran K, Chew CSE. Caring for Children and Adolescents With Eating Disorders in the Current Coronavirus 19 Pandemic: A Singapore Perspective. J Adolesc Heal. Elsevier Inc.; 2020;1-4.

[54] Wind TR, Rijkeboer M, Andersson G, Riper H. The COVID-19 pandemic: The 'black swan' for mental health care and a turning point for e-health. Internet Interv. Elsevier; 2020;20:100317.

[55] Zhang J, Lu H, Zeng H, Zhang S, Du Q, Jiang T, et al. The differential psychological distress of populations affected by the COVID-19 pandemic. Brain, Behav Immun J. 2020;87:49-50. 
[56] Zhang Y, Ma ZF. Impact of the COVID-19 pandemic on mental health and quality of life among local residents in Liaoning Province, China: A cross-sectional study. Int J Environ Res Public Health. 2020;17.

[57] Fetzer T, Witte M, Hensel L, Jachimowicz JM, Haushofer J, Ivchenko A, et al. Perceptions of an Insufficient Government Response at the Onset of the COVID-19 Pandemic are Associated with Lower Mental Well-Being. PsyArXiv. 2020;

[58] Zhu S, Wu Y, Zu C, Hong W, Yu Z, Chen Z, et al. The immediate mental health impacts of the COVID-19 pandemic among people with or without quarantine managements. Brain Behav Immun. 2020;87:56-8.

[59] Mazza C, Ricci E, Biondi S, Colasanti M, Ferracuti S, Napoli C, et al. A nationwide survey of psychological distress among Italian people during the covid-19 pandemic: Immediate psychological responses and associated factors. Int J Environ Res Public Health. 2020;17:1-14.

[60] Mallett R, Hagen-Zanker J, Slater R, Duvendack M. The benefits and challenges of using systematic reviews in international development research. J Dev Eff. 2012;4:445-55. 